\title{
A Transdisciplinary Approach for the Development of Sustainable Yam (Dioscorea sp.) Production in West Africa
}

\author{
Delwendé Innocent Kiba ${ }^{1,2, *}$, Valérie Kouamé Hgaza ${ }^{3,4}$, Beatrice Aighewi ${ }^{5}$, Sévérin Aké ${ }^{6}$, \\ Dominique Barjolle ${ }^{7}{ }^{\oplus}$, Thomas Bernet ${ }^{8}$, Lucien N. Diby ${ }^{9}$, Léa Jeanne Ilboudo ${ }^{9}$, Gian Nicolay ${ }^{8}$, \\ Esther Oka ${ }^{10}$, Florence Y. Ouattara ${ }^{10}$, Nestor Pouya ${ }^{6}$, Johan Six ${ }^{7}$ and Emmanuel Frossard ${ }^{1}$ \\ 1 Group of Plant Nutrition, Institute of Agricultural Sciences, ETH Zurich, 8315 Lindau, Switzerland; \\ emmanuel.frossard@usys.ethz.ch \\ 2 Institut de l'Environnement et Recherches Agricoles, 01 BP 476 Ouagadougou, Burkina Faso \\ 3 Centre Suisse de Recherches Scientifiques en Côte d'ivoire, 01 BP 1303 Abidjan, Ivory Coast; \\ hgaza.kouame@csrs.ci \\ 4 Département d'Agrophysiologie des Plantes, Université Peleforo Gon Coulibaly, BP 1328 Korhogo, \\ Ivory Coast \\ 5 International Institute for Tropical Agriculture, PMB 82, 901101 Abuja, Nigeria; B.Aighewi@cgiar.org \\ 6 Laboratoire de Physiologie Végétale, Université Félix Houphouët Boigny, 22 BP 582 Abidjan, Ivory Coast; \\ akeseverin08@yahoo.fr (S.A.); nestaledja@gmail.com (N.P.) \\ 7 Group of Sustainable Agroecosystems, Institute of Agricultural Sciences, ETH Zurich, 8092 Zurich, \\ Switzerland; barjolle@ethz.ch (D.B.); johan.six@usys.ethz.ch (J.S.) \\ 8 Research Institute of Organic Agriculture, 5070 Frick, Switzerland; gian.nicolay@fibl.org (G.N.); \\ thomas.bernet@fibl.org (T.B.) \\ 9 World Agroforestry Centre (ICRAF), Côte d'Ivoire Country Programme, BP 2823 Abidjan, Ivory Coast; \\ L.Diby@cgiar.org (L.N.D.); J.Ilboudo@cgiar.org (L.J.I.) \\ 10 Laboratoire d'Analyse des Dynamiques Sociales et du Développement, Université d'Abomey-Calavi, BP 526 \\ Cotonou, Benin; estheroka2014@gmail.com (E.O.); yabile.ouattara@gmail.com (F.Y.O.) \\ * Correspondence: delwende.kiba@usys.ethz.ch
}

Received: 4 April 2020; Accepted: 11 May 2020; Published: 14 May 2020

check for updates

\begin{abstract}
Yam (Dioscorea sp.) is an understudied tuber crop despite its importance for food security, income generation, culture, and health in West Africa. Traditional yam cropping practices in West Africa deliver low yields and lead to environmental degradation. In the context of a 'research for development' project, we developed and implemented a participatory and transdisciplinary research approach as a means to derive more sustainable yam production practices. We identified and studied different soil and plant management technologies adapted to varying biophysical and socio-economic contexts. For this purpose, we established innovation platforms (IPs) in four yam growing regions of West Africa, to validate the new technologies and to promote their adoption. These co-developed technologies were set up and tested first in researcher-managed plots before doing the same in farmer-managed plots. The new technologies resulted in a significant increase in yam productivity compared to conventional practices. The results discussed in the IPs gained interest from regional stakeholders and were shared through the media at local and national levels. Overall, this development-focused research approach showcases the relevance of purposeful stakeholder involvement to improve agricultural research outcomes.
\end{abstract}

Keywords: yam; innovation platform; co-development of technologies; West Africa 


\section{Introduction}

Yam (Dioscorea sp.) is a tuber crop that feeds about 300 million people in the world [1]. It is an important source of income, especially for smallholder farmers in West Africa, while serving as a medicinal crop in some regions of production [2]. The two yam species, D. rotundata and D. alata dominate production in west Africa. The origin of D. rotundata is West Africa, while that of D. alata is South-East Asia and Oceania and is present in all the tropics. Rooted in the local history, yam also has a high socio-cultural importance in many communities of West Africa [3].

West Africa produces about 90\% of yam in the world [4]. The "yam belt" spans from the humid forest to the Guinean savannah in the north-south direction and from Côte d'Ivoire to Cameroon in the east-west direction [5]. In the region, yam is traditionally cropped through slash-and-burn agriculture and requires high soil fertility [6]. The duration of the yam growth cycle depends on the cultivar and period of rainfall, varying from six to 12 months from shoot emergence to senescence. Yam is cultivated on mounds or ridges by planting small whole seed tubers or portions of the tuber that contain a part of the epidermis. The plant may be staked depending on the cultivar and local cultural practices and harvested tubers can be stored for up to six months [5]. Traditionally, yam is cropped without using external inputs [6]. According to FAOSTAT (Food and Agricultural Organization of the United Nations On-line and Multilingual Database), the tenfold increase in yam tuber production observed within the last 50 years has been driven by a sevenfold increase in cultivated areas [4]. However fresh tuber yields have increased by only $14 \%$ during the same period.

A lot of challenges impede the increase of yam productivity. First, there is a lack of fundamental knowledge about the crop. While it was highlighted a multitude of factors that can affect yam productivity such as weather conditions, seed weight and quality, cultivar, planting density and date, staking, disease, weed management, and plot history [7], their real effects on tuber productivity are not well-known. This lack of knowledge strongly limits agricultural extension activities for the crop. Secondly, African governments provide very little support for the development of new technologies to improve yam productivity in comparison to other crops like maize, sweet potato, cassava, cotton, cocoa, or cashew. Thirdly, conventional research approaches in yam systems do not allow a good uptake of new technologies. Indeed, in the review on the challenges for improving soil fertility in yam cropping systems in West Africa, it was stated that the application of integrated soil fertility management in yam-based systems should be related to the preferences of different actors along the value chain [6]. The same review also stated that sustainable improvement of yam productivity would require a transdisciplinary approach to allow inputs from practice into research and vice versa. This approach would better define the problem and co-design acceptable and feasible solutions.

Transdisciplinary approaches are known to involve stakeholders from various domains of science and practice in information exchange and mutual knowledge development [8]. The approach has shown the potential in solving problems in the fields of environment and health, urban and landscape development, and adoption of new technologies [9]. Innovation platforms (IPs) are a useful tool in the transdisciplinary approach as they allow multi-stakeholder interactions, and the marshaling of ideas, people, and resources to resolve specific societal problems [10].

This study is the first that shows how a transdisciplinary approach can be used to sustainably improve yam productivity in West Africa. It aims to present the experiences in setting up innovation platforms as a tool to develop, in a transdisciplinary manner, soil and plant management technologies that are adapted to various biophysical and socio-economic contexts. The study also tried to determine the extent to which the technologies were adopted.

We hypothesized that IPs allow an objective identification of the bottlenecks of yam production by considering the opinions of researchers and various yam value chain stakeholders as well as the co-development of acceptable technologies that contribute to increase yam productivity sustainably at farm level. To test this hypothesis, we organized yam stakeholders in IPs in four yam growing regions of West Africa and used a stepwise process to co-develop technologies. Then, we assessed the technologies on researchers' - and farmers' - managed plots to note their impact in improving yam 
productivity and the level of interest of farmers in them. In this paper, we present the characteristics of the yam growing regions, and the methods used to organize stakeholders in IPs and work with them. Then, we discuss the findings relating to the activities of IPs, including the co-development of technologies, and their evaluation in farmers' fields. Finally, we present the limits of the study, the challenges faced, and lessons learned.

\section{Materials and Methods}

\subsection{The Yam Growing Regions}

\subsubsection{Biophysical and Socio-Economic Characteristics}

The work was conducted in two yam growing regions in Côte d'Ivoire (Liliyo in the south west and Tiéningboué in the centre), and two regions in Burkina Faso (Midebdo in the south west and Léo in the south). The regions were located along a gradient of vegetation and rainfall from the south west of Côte d'Ivoire to the south of Burkina Faso (Table S1 of supplementary material). The land use as described with the Land Degradation Surveillance Framework [11] showed that cropland (mostly perennial plantation of cocoa and oil palm) fully covered the region of Liliyo [12], while cropland covered about $50 \%$ of the lands in Tiéningboué and Léo, and 23\% of Midebdo. Forest was present only in Tiéningboué and covered about $1 \%$ of the area. The study of Baumann showed that soil surface horizons sampled from yam fields had the highest values of total carbon and clay contents in Tiéningboué, whereas the lowest values were observed in Léo [13]. The highest soil water infiltration rate was also recorded in Tiéningboué $(425 \mathrm{~mm} / \mathrm{h})$ and the lowest in Léo $(162 \mathrm{~mm} / \mathrm{h})$.

The studied yam growing regions with the rapid rural appraisal method [14] showed different autochthonous and migrant groups across the four regions (Table S2 of supplementary material). The highest population densities were found in Liliyo (150 inhabitants $\left./ \mathrm{km}^{2}\right)$ followed by Léo $(75$ inhabitants $\left./ \mathrm{km}^{2}\right)$, Tiéningboué (31 inhabitants $\left./ \mathrm{km}^{2}\right)$, and Midebdo (25 inhabitants $\left./ \mathrm{km}^{2}\right)$. Yam was found to be a staple food crop in Tiéningboué, Midebdo, and Léo but not in Liliyo where the staple food crop was rice.

\subsubsection{Cropping Practices}

Yam cropping practices varied across the different regions. Local yam varieties were mostly cropped at the regions. However, improved varieties were observed in Liliyo (C18) and in Midebdo and Léo (Florido) (Table 1). In Liliyo, cash crops including cocoa are priority crops for farmers, while the cultivation of food crops is of less importance. In addition, yam was often planted after a fallow, or in an old or diseased cocoa farm plantation. In Tiéningboué and Léo, yam was intercropped with cereal and legume after a fallow. Yam was rarely intercropped in Léo while in Tiéningboué and Liliyo intercropping of yam with vegetables, banana, taro, cassava, or cocoa and cashew (when the trees are young) was very common. In Midebdo yam was intercropped with millet. Mineral fertilizer application on yam was only observed in Léo. Herbicides were used in all the regions, except in Midebdo. The yam planting density was higher in Côte d'Ivoire than in Burkina Faso.

\subsection{Setting up Innovation Platforms}

In each region, a rapid rural appraisal (RRA) was conducted. Discussions in consultation groups allowed identifying between 18 to 26 key stakeholders per region who volunteered to become IP members without any compensation (Table 2). These members included researchers (agronomists, economists, and sociologists), farmers, traders, transporters, processors, agricultural extension agents, input suppliers, media, microfinance institutions and security agents as well as traditional, religious, and administrative authorities. 
Table 1. Current yam cropping systems of selected farms and soil properties of four regions in Burkina Faso and Côte d'Ivoire. The cropping practices and yam productivity were described by Pouya in Burkina Faso [15] and Ouédraogo in Côte d'Ivoire [16].

\begin{tabular}{|c|c|c|c|c|c|}
\hline \multirow{2}{*}{\multicolumn{2}{|c|}{ Cropping Practices }} & \multicolumn{4}{|c|}{ Regions } \\
\hline & & Liliyo & Tiéningboué & Midebdo & Léo \\
\hline \multicolumn{2}{|c|}{$\begin{array}{c}\text { Dominant yam species (and } \\
\text { variety) }\end{array}$} & D. alata (C18) & $\begin{array}{l}\text { D. alata } \\
\text { (woroba)/D. } \\
\text { rotundata } \\
\text { (krenglè) }\end{array}$ & $\begin{array}{l}\text { D. alata (florido)/D. } \\
\text { rotundata (pahinté) }\end{array}$ & $\begin{array}{l}\text { D. alata } \\
\text { (florido)/ } \\
\text { D. rotundata } \\
\text { (wassara, } \\
\text { sandjarè, } \\
\text { pouna) }\end{array}$ \\
\hline \multicolumn{2}{|c|}{$\begin{array}{l}\text { Most common position of yam in } \\
\text { typical rotations }\end{array}$} & $\begin{array}{l}\text { Fallow or old cocoa } \\
\text { plantation/yam/with } \\
\text { groundnut or } \\
\text { cassava /new cocoa } \\
\text { plantation }\end{array}$ & $\begin{array}{l}\text { Fallow/yam/maize } \\
\text { or rice or grain } \\
\text { legumes/yam }\end{array}$ & $\begin{array}{c}\text { Fallow/yam/maize } \\
\text { or groundnut or } \\
\text { sorghum/millet }\end{array}$ & $\begin{array}{c}\text { Fallow/maize } \\
\text { or groundnut } \\
\text { or cowpea/yam }\end{array}$ \\
\hline \multicolumn{2}{|c|}{$\begin{array}{l}\text { Most common intercropping } \\
\text { including yam }\end{array}$} & $\begin{array}{c}\text { Yam + early stage } \\
\text { cocoa trees } \\
\text { Byam + vegetables }\end{array}$ & $\begin{array}{c}\text { Yam }+ \text { early stage } \\
\text { cashew trees } \\
\text { Byam }+ \\
\text { vegetables }\end{array}$ & Yam + millet & None \\
\hline \multicolumn{2}{|c|}{ External inputs in yam fields } & $\begin{array}{l}\text { Glyphosate to clear } \\
\text { the land }\end{array}$ & $\begin{array}{l}\text { Glyphosate to } \\
\text { clear the land, } \\
\text { mineral } \\
\text { fertilizers added } \\
\text { to maize and rice }\end{array}$ & None & $\begin{array}{c}\text { Mineral } \\
\text { fertilizers and } \\
\text { manure added } \\
\text { to yam, maize, } \\
\text { pre and post } \\
\text { emergence } \\
\text { herbicides used } \\
\text { against weeds }\end{array}$ \\
\hline \multirow{2}{*}{$\begin{array}{c}\text { Number of } \\
\text { mounds }\left(10^{3}\right. \\
\text { mounds/ha) }\end{array}$} & D. alata & $13.5(2.4)$ & $7.6(1.2)$ & $4.0(0.3)$ & na \\
\hline & D. rotundata & na & $7.5(2.0)$ & $4.0(0.3)$ & $4.9(0.4)$ \\
\hline
\end{tabular}

Note: The number of mounds per hectare was determined on four plots of $5 \times 5 \mathrm{~m}$; data in parentheses are standard

deviations; $\mathrm{na}=$ not applicable (no field with the corresponding yam species was investigated).

Table 2. Categories of stakeholders of innovation platform (IP) for yam in four yam growing regions in Burkina Faso and Côte d'Ivoire.

\begin{tabular}{ccccc}
\hline \multirow{2}{*}{ Category of Stakeholders } & \multicolumn{3}{c}{ Regions } \\
\cline { 2 - 5 } & Liliyo & Tiéningboué & Midebdo & Léo \\
\hline Researchers & 2 & 2 & 2 & 2 \\
Farmers & 4 & 6 & 6 & 6 \\
Traders & 1 & 1 & 2 & 1 \\
Transporters & na & na & na & 1 \\
Processors & 1 & na & 2 & 1 \\
Extension agents & 2 & 3 & 3 & 5 \\
Inputs suppliers & 1 & 1 & 1 & 1 \\
Microfinances & na & 1 & 1 & 1 \\
Media & na & 1 & na & 1 \\
Security agents & na & 1 & na & na \\
Traditional authorities & 5 & 4 & 2 & 2 \\
Religious authorities & 1 & 1 & na & 23 \\
Administrative authorities & 1 & 5 & 6 & \\
\hline Total & 18 & 26 & 25 & \\
\hline
\end{tabular}

Note: na $=$ not applicable (no stakeholder was not found for this category).

The IPs identified the problems related to yam systems and co-developed potential solutions which were tested. The results were then discussed and communicated to the stakeholders and the 
public through the government administrative authorities (Figure 1). The researchers moderated the IP meetings. The first meeting of each IP was used to decide on the name for the IP and develop a joint vision. The meetings were documented, and the minutes shared with all the IP members.

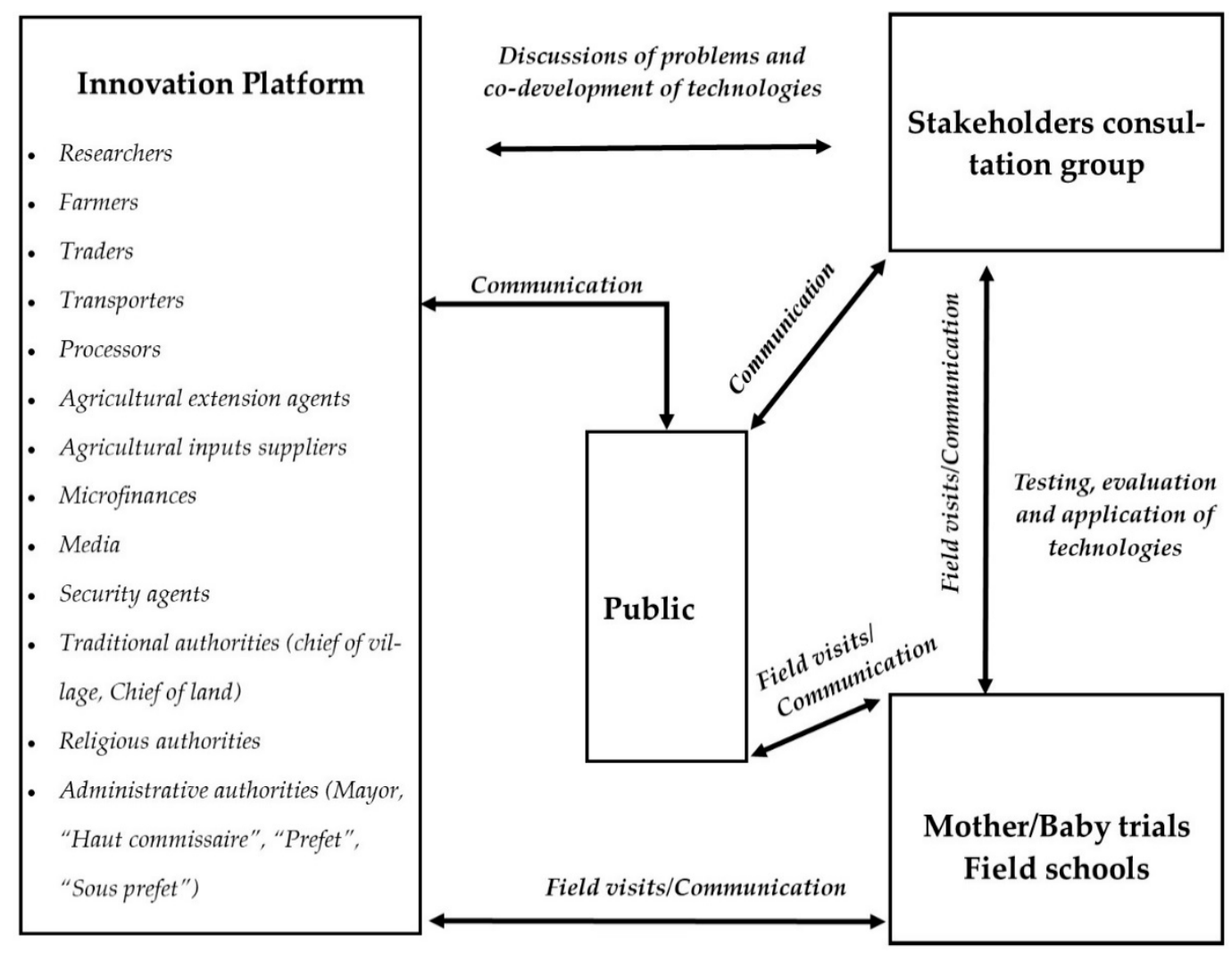

Figure 1. Organization and functioning of innovation platform for yam in Burkina Faso and Côte d'Ivoire. The IP is composed of various groups of stakeholders and local government authorities. The stakeholders organize meetings to identify problems that are brought to the IP. The IP identifies solutions that are taken to the stakeholders and tested in research-managed plots (mother trials) and then in farmers' fields (baby trials). Farmers are trained in field schools by researchers. The authorities in the IP convey the decisions to the public as well as representatives of stakeholders' groups through stakeholders' meetings and during visits to the field trials.

\subsection{Problems Ranking in Yam Production and Co-Development of Technologies}

Each group of stakeholders (researchers, farmers, traders, etc.) met to identify the problems they perceived as most important in the yam value chain of their region. Then the IP members representing the different groups brought the problems to the IP meetings. Only problems raised by at least three members from different groups of stakeholders were discussed and ranked. For each problem, technologies to solve it were proposed by IP members. These technologies were then reported by the representatives to their respective groups for feedback. The feedbacks were then discussed in another IP meeting and the most acceptable technologies were selected.

In 2016, most of these technologies were tested in field trials managed by researchers, "mother trials," while training on seed treatment and improved storage and fertilizers application was provided to the farmers in field schools by the researchers upon request of the IP. The technologies were tested and were constantly evaluated by IP members, resulting after each year in new adaptations (Figure 2) based on the experiment results of the researchers and the concerns of the practitioners. For instance, researchers proposed the use of improved yam varieties to solve the problem of diseases, whereas yam farmers from Léo proposed the use of ashes to treat seed yam before planting and the national water 
and forestry commission of Tiéningboué proposed the introduction of improved staking method to reduce deforestation. All these propositions were tested.

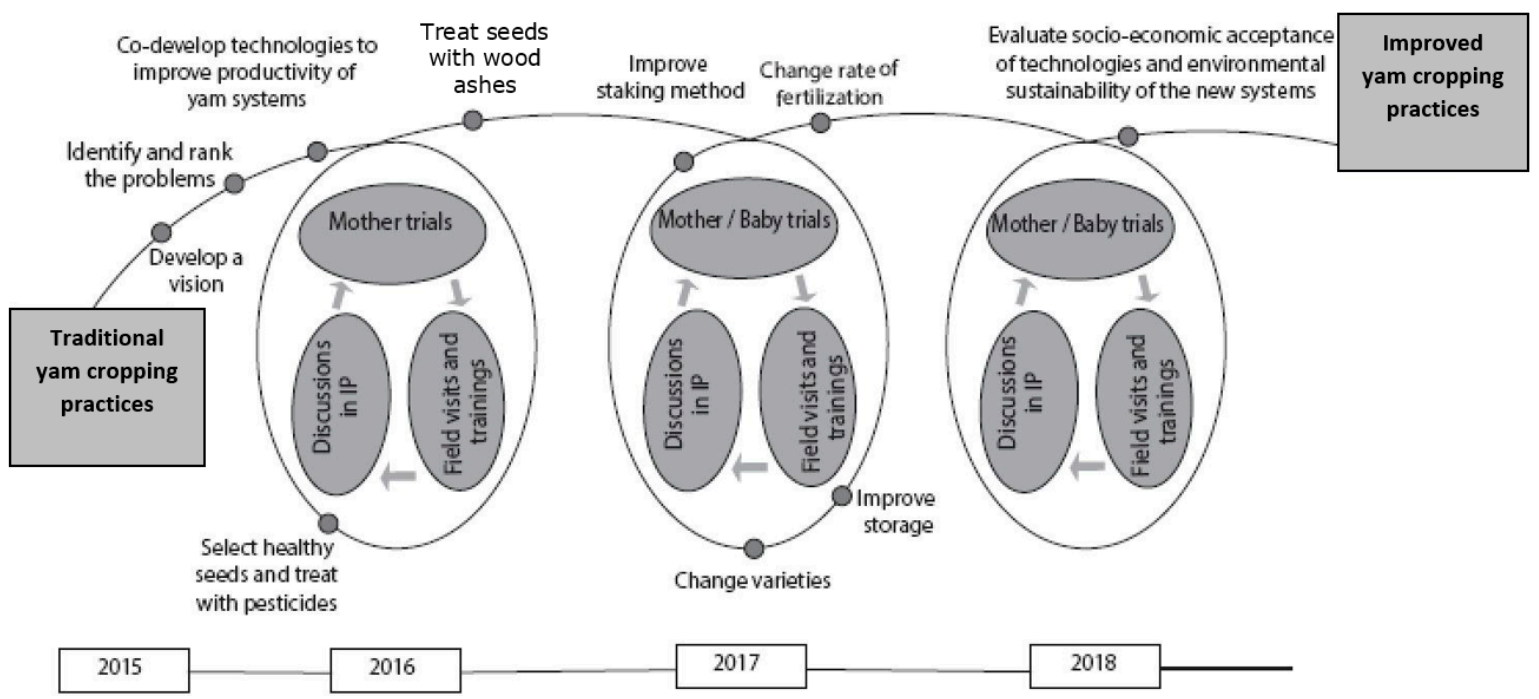

Figure 2. Stepwise co-development of yam production technologies through IPs established in four yam growing regions of West Africa between 2015 and 2018. The small circles show the different steps of co-development of technologies, evaluation, adaptation of technologies, new evaluation.

\subsection{Transfer of Technologies from Research to Farmers' Fields}

In 2017, the "baby trials" were set up in farmers' fields, with each comprising two plots of equal size, one named $\mathrm{T} 1$ where a set of technologies chosen by the farmer was tested and a control named $\mathrm{T} 0$ which was managed according to farmers' traditional practice. The size of the T1 plots varied from 100 to $312 \mathrm{~m}^{2}$ depending on the land area that the farmer decided to allocate to the trial. The T1 and T0 plots were generally spaced apart from each other by about a maximum of $20 \mathrm{~m}$ to minimize the risk of high heterogeneity. The farmers decided on the yam field and where to allocate the T0 and T1 plots. However, before applying the technologies in the T1 plots, we ensured that there were no visible signs of differences in soil properties (soil color, soil texture, signs of erosion, cropping history) and slope of land between the two plots.

Farmers tested a combination of two technologies or more. The T0 planting and harvest dates were fixed by the farmers according to their usual practices. In 2017, farmers requested the assistance of researchers in their T1 plots for specific operations such as seed treatment, mounds making at a density of $1 \mathrm{mound} / \mathrm{m}^{2}$, and fertilizer application which resulted in delayed planting. From 2018, the baby trials were set up by the farmers themselves. The mineral fertilizers, pesticides, and yam seeds were provided to farmers by the researchers, while organic fertilizers were sourced locally by the farmers. At harvest, the germination rate was estimated by considering the number of mounds having yam plant divided by the total number of mounds in the plot. The total and marketable fresh tuber yields were measured by the researchers. Information was collected on date of planting, number of weeding, as well as rate and type of fertilizers applied in T0 and T1 plots. The marketable fresh tuber yield was measured based on the marketable tubers selected according to the opinion of the farmer. Data on the baby trials of Midebdo in 2017 were not collected because the research protocol (plots size and allocation) was not fully respected.

\section{Results and Discussion}

\subsection{Names and Visions of Innovation Platforms}

The names and visions given by the members to their IPs (Table 3) were indicative of the expectations they had from this transdisciplinary research. For example, by naming the IP "Lets crop 
yam" in Liliyo, the group wanted to express the fact that rice (their favorite food crop) cropping was becoming difficult due to scarcity of low lands and bird attacks, and therefore yam was foreseen as a solution. In Tiéningboué, "Hope" signified that the IP members hoped to improve their livelihoods through yam production. In Midebdo, "Wake up yam" was chosen to highlight the fact that farmers in this region used to be the best yam producers, but now there is a dire need to revive this past performance. In Léo, "Star of yam" was selected to express the importance of yam for the people, and the desire to increase production.

Table 3. Name given and vision of the innovation platforms (IPs) for yam system located at four studied regions in Burkina Faso and Côte d'Ivoire.

\begin{tabular}{ccccc}
\hline $\begin{array}{c}\text { IP Name and } \\
\text { Vision }\end{array}$ & Liliyo & Tiéningboué & Midebdo & Léo \\
\hline IP name & $\begin{array}{c}\text { Aglossié (Bété } \\
\text { language) } \\
\text { Let's crop yam }\end{array}$ & $\begin{array}{c}\text { Djiguisêmê (Kôro } \\
\text { language) } \\
\text { Hope }\end{array}$ & $\begin{array}{c}\text { Si-Jia-Por (Lobiri } \\
\text { language) } \\
\text { Wake up yam }\end{array}$ & $\begin{array}{c}\text { Pia-kakila-kio } \\
\text { (Gourounsi language) } \\
\text { Star of yam }\end{array}$ \\
\cline { 2 - 5 } IP vision & $\begin{array}{c}\text { Increase yam and } \\
\text { rice production to } \\
\text { decrease expenses } \\
\text { for food }\end{array}$ & $\begin{array}{c}\text { Develop cropping } \\
\text { systems that } \\
\text { preserve the } \\
\text { environment and } \\
\text { increase yam yields }\end{array}$ & $\begin{array}{c}\text { Develop yam seed } \\
\text { and processing } \\
\text { sectors }\end{array}$ & $\begin{array}{c}\text { Make yam the pillar of } \\
\text { the local economy by } \\
\text { improving yam } \\
\text { quantity and quality }\end{array}$ \\
\hline
\end{tabular}

The vision of the IP members in Liliyo suggests that an increase in yam and rice production will lead to decreased food expenses. Indeed, cocoa and other cash crops (rubber trees, oil palm) leave very limited land for food crops. Farmers thus use part of their income from cash crops to buy food. It was interesting to note that in Tiéningboué, the only region which still had some forest area, the IP wanted to develop environmentally friendly yam production practices, i.e., involving less deforestation and less wood cutting for training yam vines. The vision proposed by the Midebdo IP to develop a processing sector was not expected given the low yam production in this region. The vision expressed in Léo indicated that a high economic value was placed on tuber crops.

\subsection{Identified Problems and co-Developed Technologies}

Discussions held in the IPs revealed that land scarcity (due to competition with perennial crops), soil fertility depletion, and lower and irregular rainfall distribution were perceived as the most important constraints for yam production. Researchers added to this list the bad quality of yam planting material (seed tubers) used by farmers. The researchers made this addition when they realized that at the four regions, farmers were not able to distinguish soil constraints from other factors such as poor seed quality.

Members of the IP discussed the technologies mentioned in Table 4 to solve the identified problems. Crop rotations and associations and increased planting density of 10,000 plants/ha were considered as a solution to land scarcity. The application of mineral and/or organic fertilizers was seen as a solution to soil fertility decline. Given the importance of healthy seed, researchers proposed to select the tubers of plants with no visible disease symptoms as seeds for the next cropping season, to use a mixture of a fungicide and an insecticide to treat seeds just before planting and to improve tuber storage in order to keep the tubers healthy until the next cropping season. 
Table 4. Identified problems of yam cropping and co-developed technologies implemented to improve yam productivity in mother trials in four studied regions in Burkina Faso and Côte d'Ivoire.

\begin{tabular}{|c|c|c|c|c|c|}
\hline \multirow{2}{*}{ Problems } & \multirow{2}{*}{ Solutions } & \multicolumn{4}{|c|}{ Solutions per Region } \\
\hline & & Liliyo & Tiéningboué & Midebdo & Léo \\
\hline $\begin{array}{l}\text { Low soil } \\
\text { fertility }\end{array}$ & Fertilization & $\begin{array}{l}\text { Water soluble mineral } \\
\text { fertilizer (WSMF) alone; } \\
\text { poultry manure (PM) } \\
\text { alone; WSMF + PM }\end{array}$ & $\begin{array}{l}\text { WSMF; PM; WSMF } \\
\quad+\text { PM }\end{array}$ & $\begin{array}{l}\text { WSMF; cow } \\
\text { manure }(\mathrm{CM}) \\
\text { WSMF + CM }\end{array}$ & $\begin{array}{l}\text { WSMF; CM; } \\
\text { WSMF + CM }\end{array}$ \\
\hline Scarcity of land & $\begin{array}{c}\text { Crops in } \\
\text { rotation with } \\
\text { yam }\end{array}$ & $\begin{array}{l}\text { Maize; groundnut; } \\
\text { cowpea }\end{array}$ & Rice; groundnut; & Maize; groundnut & Maize; groundnut \\
\hline Scarcity of land & $\begin{array}{l}\text { Crops } \\
\text { intercropped } \\
\text { with yam }\end{array}$ & Maize & Maize & Millet & Cowpea \\
\hline $\begin{array}{c}\text { Bad } \\
\text { performance of } \\
\text { traditional yam } \\
\text { varieties }\end{array}$ & $\begin{array}{l}\text { Introduce new } \\
\text { yam species } \\
\text { (varieties) }\end{array}$ & $\begin{array}{l}\text { D. alata: (C18) in 2016, } \\
\text { and 2018; D. rotundata: } \\
\text { (R3) in } 2017\end{array}$ & $\begin{array}{l}\text { D. alata: (Woroba) } \\
\text { in 2016, 2017; (C18) } \\
\text { in 2018; D. } \\
\text { rotundata: (Krenglè) } \\
\text { in 2016, 2017; (R3) } \\
\text { in 2018 }\end{array}$ & $\begin{array}{l}\text { D. alata:(Florido) in } \\
\text { 2016;(C18) in 2018; } \\
\text { D. rotundata: } \\
\text { (Pahinté) in 2017; } \\
\text { (R3) in } 2018\end{array}$ & $\begin{array}{l}\text { D. alata: (Florido) } \\
\text { in 2016; (C18) in } \\
\text { 2018; D. rotundata: } \\
\text { (Wassara) in 2017; } \\
\text { (R3) in } 2018\end{array}$ \\
\hline Scarcity of land & $\begin{array}{l}\text { Increased } \\
\text { planting } \\
\text { density to } 1 \\
\text { plant } / \mathrm{m}^{2}\end{array}$ & Yes & Yes & Yes & Yes \\
\hline $\begin{array}{l}\text { Poor seed } \\
\text { quality }\end{array}$ & $\begin{array}{l}\text { Seed treatment } \\
\text { with wood ash } \\
\text { and fungicide }\end{array}$ & Yes & Yes & Yes & Yes \\
\hline Poor storage & $\begin{array}{l}\text { Improved } \\
\text { Storage }\end{array}$ & Yes & Yes & Yes & Yes \\
\hline $\begin{array}{l}\text { Deforestation } \\
\text { to produce } \\
\text { stakes }\end{array}$ & $\begin{array}{l}\text { Improved } \\
\text { Staking }\end{array}$ & Yes & Yes & Yes & Yes \\
\hline
\end{tabular}

Notes: Improved storage to maintain seed quality till the next harvest; staking using fewer wood and strings to train the vines on strings of $D$. rotundata.

Farmers decided to use wood ash as seed treatment, recalling that this was the practice of their forefathers instead of the insecticide suggested by researchers. In Tiéningboué, Midebdo, and Léo, farmers wanted to produce seeds of local yam varieties (woroba, wassara, pahinté, and krenglé) because they are highly appreciated by consumers for their taste, suitability for processing and the preparation into specific dishes, as well as having high market value. However, after obtaining yields of more than $40 \mathrm{t} /$ ha for the D. alata variety C18 in Liliyo in 2016 (Figure S1 of supplementary material), and observing the presence of many black spots within the tubers of the traditional varieties-a sign of poor tuber quality-the IP members decided to introduce variety C18 in all the mother trials in 2018. Nevertheless, researchers subsequently found a high variability in the response of C18 to soil fertility management with very heterogeneous tuber yields, making this variety difficult to control. Farmers then became more interested in another variety of $D$. rotundata (referred to as R3) which responded better to soil fertility management and attained the highest yield in Léo (15 t/ha) (Figure S2 of the supplementary material).

In Midebdo and Léo where significant responses of yam tuber yield in the mother trials were not observed (Figure S1 of the supplementary material) because of late planting and poor soil properties respectively, farmers were still convinced on the positive effects of the new technologies by seeing the differences in the volume of yam foliage (biomass). The last technology was a staking system using less wood compared to the traditional practice which requires a large quantity of wood, thus contributing to deforestation. A staking system based on using strings to train the vines was proposed by two members of the National Water and Forestry Commission in the IP of Tiéningboué.

The similarities between the technologies implemented at each region can be explained by the similarities of problems encountered, and by the fact that there was an intense communication between regions mediated by the researchers. Nevertheless, the technologies were adapted to the local contexts, 
considering different crops, different types of organic matter inputs (poultry manure in Côte d'Ivoire vs. cattle manure in Burkina Faso), and different rotations. Besides, these similarities can also be explained by migration (leading to a mixing of populations), leading to a progressive change in habits and finally to similar needs despite differences in the autochthonous groups between regions. For instance, yam cropping in Liliyo was introduced by the Baoulés who migrated in the 1980s from the center of Côte d'Ivoire to grow plantation crops, especially cocoa [17]. Recently, Bété people who are autochthonous to the region of Liliyo and who usually grow rice, have started to produce yam probably because of the influence of the Baoulés. Similarly, the Mossi ethnic group, known as cereal producers, who immigrated to Léo from the central plateau of Burkina Faso in search of better land and a better climate [18], also became yam producers.

\subsection{Application of the Technologies in Farmers' Fields}

The stakeholders have various preferences for varieties as attested by the diversity of varieties they selected to achieve healthy seed production (Table 5). The low number of trained farmers in Midebdo indicate a low interest of farmers from this region to our investigations compared to the other regions.

Table 5. Healthy yam seed production in 2016 in four yam growing regions in Burkina Faso and Côte d'Ivoire.

\begin{tabular}{ccccc}
\hline Seed Production Aspects & Liliyo & Tiéningboué & Midebdo & Léo \\
\cline { 2 - 5 } & 73 & 59 & 18 & 105 \\
\hline $\begin{array}{c}\text { Number of farmers trained } \\
\text { Number of seed of 200-250 g } \\
\text { produced }\end{array}$ & 50,345 & 36,307 & 4370 & 14,763 \\
$\begin{array}{c}\text { Surface that can be sown } \\
\text { with the seeds (ha) }\end{array}$ & 5.03 & 3.63 & 0.44 & 1.48 \\
Species (varieties) produced & D. alata (C18) & $\begin{array}{c}\text { D. alata (woroba), } \\
\text { D. rotundata } \\
\text { (krenglé) }\end{array}$ & D. alata (florido) & $\begin{array}{c}\text { D. rotundata } \\
\text { (wassara) }\end{array}$ \\
\hline
\end{tabular}

In the baby trials conducted in 2017, the fresh yam tuber yields were highly variable both in the T0 and T1 plots (Table 6). This could be explained by different factors such as plot history, soil quality, planting and harvest dates, size of seed tubers, weeding regime, and the amount of fertilizers applied. These factors probably affected the crop establishment, which is critical in determining yam yield [7]. The high variability of yields also explains the low yield difference between the plots where technologies were applied and farmers' practice plots. Nevertheless, the difference in total fresh tuber yield for D. alata was higher in Liliyo ( $5 \mathrm{t} / \mathrm{ha}$ ) compared to Tiéningboué (1.8 t/ha), probably due to the use of improved varieties, which have higher yield potential and disease resistance [19]. The difference in total fresh tuber yield for $D$. rotundata is higher in Tiéningboue ( $5.7 \mathrm{t} / \mathrm{ha})$ than in Léo (2.3 $\mathrm{t} / \mathrm{ha}$ ), probably due to the high technicity of the farmers in Léo. Indeed, farmers from Léo were used to applying mineral and organic fertilizers on yam, while in Tiéningboué fertilizers are only applied on crops other than yam, like maize and rice (Table 3). Similarly, difference in marketable fresh tuber yield due to the technologies were observed in Liliyo (4.16 t/ha) for D. alata and Tiéningboué for $D$. rotundata $(4.43 \mathrm{t} / \mathrm{ha}$ ) while no significant difference was observed in Léo. The yam germination rates in all the plots were higher than $80 \%$ and, except for D. alata in Liliyo, no significant difference was observed between the T0 and T1 plots. This good germination rate is due to the fact that farmers applied seed treatments in their T0 plots as they rapidly realized its positive effect in the mother trials. The difference in the germination rate between $\mathrm{T} 1$ and $\mathrm{T} 0$ plots in Liliyo is probably due to an effect of the improved variety. 
Table 6. Yield responses of yam species of D. alata and D. rotundata to technologies in farmers' plots (baby trials) in three yam growing regions in Burkina Faso and Côte d'Ivoire in 2017.

\begin{tabular}{|c|c|c|c|c|c|}
\hline \multirow{2}{*}{ Species } & \multirow{2}{*}{ Yield Aspects } & \multirow{2}{*}{ Treatments } & \multicolumn{3}{|c|}{ Regions } \\
\hline & & & Liliyo & Tiéningboué & Léo \\
\hline \multirow{9}{*}{ D. alata } & \multirow{3}{*}{$\begin{array}{l}\text { Total fresh } \\
\text { tuber yield } \\
\text { (t/ha) }\end{array}$} & T1plots 1 & $11.13(6.05)$ & $7.97(4.78)$ & na \\
\hline & & T0 plots & $6.25(3.71)$ & $6.18(5.36)$ & na \\
\hline & & $p$-value ${ }^{2}$ & $<0.001$ & 0.138 & na \\
\hline & \multirow{3}{*}{$\begin{array}{l}\text { Marketable } \\
\text { fresh tuber } \\
\text { yield (t/ha) }\end{array}$} & T1plots & $8.18(5.69)$ & $4.98(4.41)$ & na \\
\hline & & T0 plots & $4.02(2.32)$ & $4.48(4.64)$ & na \\
\hline & & $p$-value & $<0.001$ & 0.730 & na \\
\hline & \multirow{3}{*}{$\begin{array}{l}\text { Germination } \\
\text { rate }(\%)\end{array}$} & T1plots & $96.0(5.24)$ & $95.7(7.89)$ & na \\
\hline & & T0 plots & 84.9 (11.8) & $94.6(6.28)$ & na \\
\hline & & $p$-value & $<0.001$ & 0.149 & na \\
\hline \multirow{9}{*}{ D. rotundata } & \multirow{3}{*}{$\begin{array}{l}\text { Total fresh } \\
\text { tuber yield } \\
\text { (t/ha) }\end{array}$} & T1plots & na & $10.02(6.08)$ & $11.58(6.25)$ \\
\hline & & T0 plots & na & $4.25(4.17)$ & $9.30(5.00)$ \\
\hline & & $p$-value & na & 0.001 & 0.068 \\
\hline & \multirow{3}{*}{$\begin{array}{l}\text { Marketable } \\
\text { fresh tuber } \\
\text { yield (t/ha) }\end{array}$} & T1plots & na & $6.93(5.41)$ & $5.53(3.21)$ \\
\hline & & T0 plots & na & $2.50(3.66)$ & $5.20(3.09)$ \\
\hline & & $p$-value & na & 0.002 & 0.620 \\
\hline & \multirow{3}{*}{$\begin{array}{l}\text { Germination } \\
\text { rate } \%\end{array}$} & T1plots & na & 90.7 (11.4) & $93.4(5.78)$ \\
\hline & & T0 plots & na & $86.9(13.1)$ & $94.2(5.03)$ \\
\hline & & $p$-value & na & 0.404 & 0.495 \\
\hline
\end{tabular}

Note: na $=$ not applicable (means no field with the corresponding yam species was investigated) ${ }^{1} \mathrm{~T} 1$ plots are the plots where technologies are tested while $\mathrm{T} 0$ plots represent the practices of the farmers; the numbers within brackets are standard deviations; 40, 33, and 43 baby trials were established in 2017 in Liliyo, Tiéningboué, and Léo, respectively; ${ }^{2} p$-value is from Chi-square Kruskal-Wallis test.

\subsection{Key Success Stories Resulting From the Study}

A survey conducted in 2018 with 44, 48, and 50 yam farmers who implemented baby trials in 2017 in Liliyo, Tiéningboué, and Léo, respectively, showed that about 9\%, 12\%, and $24 \%$ of them, respectively, deliberately decided to apply the technologies on the total surface of their fields in 2018 (Figure 3). The higher adoption of technologies by farmers across their fields in Léo and Tiéningboué could be explained by the marketing network developed due to the large wholesale market in Bouaké [20] near Tiéningboué and the proximity of Léo to the Ghanaian border, which offers cross-border marketing opportunities. However, the investigation also showed that a greater proportion of farmers in Tiéningboué (40\%) and Léo (24\%) did not adopt any technology, compared to Liliyo. As Tiéningboué and Léo are traditional yam-growing areas, some farmers may not initially trust these technologies because they have a high level of confidence in their traditional knowledge. In Liliyo, the high population density due to the influx of national and international migrants attracted by employment opportunities along the cocoa value chain [21] is putting pressure on land. This would explain why farmers allocated only a small area of their fields to adopt the technologies.

During the yam forum in February 2019 in Léo, a yam farmer trained in a field school by the researchers was awarded the "best yam farmer." In Léo, a farmer started to produce seed yam to sell to other farmers thanks to the technologies he learnt. In Liliyo, a farmer from the Bété ethnic group who conducted a baby trial increased his yield from $4 \mathrm{t} / \mathrm{ha}$ in 2017 when using his traditional practices to 19 $\mathrm{t} / \mathrm{ha}$ in 2018 in the same field using the co-developed technologies. In Midebdo, an old farmer (known as "Chef des Terres") expressed his gratitude when he realized that an increase in yam planting density allowed him to reduce his field surface without reducing his yam production. 


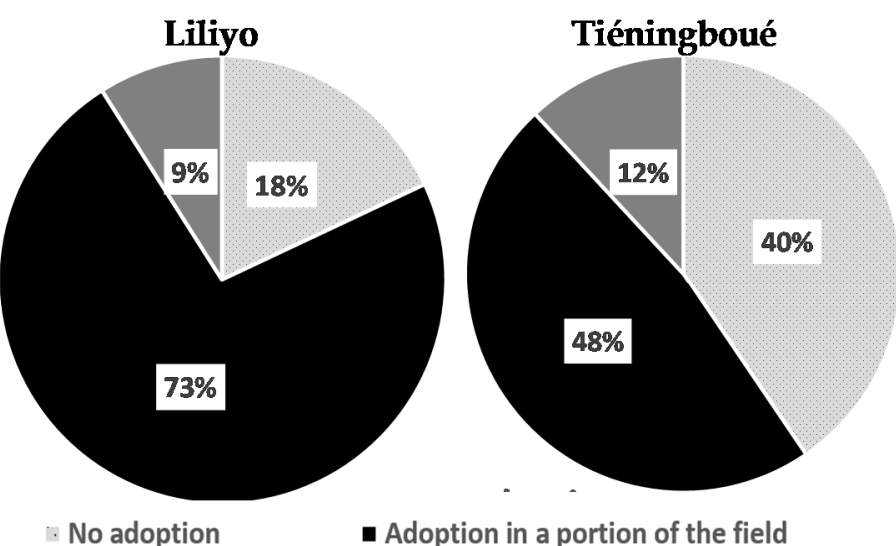

No adoption
- Adoption in a portion of the field

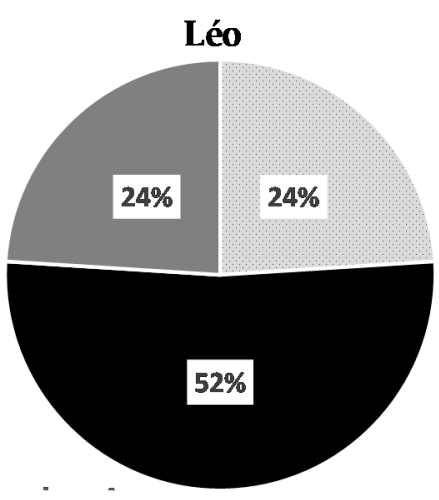

घdoption in the whole field

Figure 3. Adoption rates of technologies to improve yam productivity at three sites in Burkina Faso and Côte d'Ivoire by yam farmers after having tested the technologies in trials that were implemented a year before in their fields by researchers. The number of farmers involved in the study is 44,48 , and 50 for Liliyo, Tiéningboué, and Léo, respectively.

Other stakeholders beyond farmers and researchers also gained benefit from the IPs. For instance, in Léo, a micro-credit institution belonging to the IP was able to offer credit for yam production because they realized that lack of financial resources was a limiting factor in investing in soil fertility management in yam production. Extension agents involved in the IPs in the four sites were trained by researchers on yam cultivation when the researchers realized their limited knowledge on the crop. In Léo, input suppliers received training from researchers at their request in order to provide better services to farmers. During an exchange visit between farmers in Léo, Tiéningboué, and Liliyo, discussions between farmers and yam traders resulted in a commitment by farmers to produce tubers between 1 and $2 \mathrm{~kg}$ to satisfy consumers' demand.

These results suggest that our transdisciplinary approach implemented through IPs and the constant feedback loops leading to technologies adaptation, motivated stakeholders to improve yam productivity by applying the co-developed knowledge.

\subsection{Limitations, Challenges, and Lessons Learnt}

The IP is an appropriate tool for stimulating dialogue among local stakeholders allowing co-development of technologies, but it has shown weaknesses when not appropriately managed. A major risk is that, as stakeholders in the IPs, researchers often dominate discussions and influence the decisions. Another point is that a limited number of representatives of stakeholders may hinder the dissemination of the results. This reaching out to their larger consultation group (Figure 1) is not often happening as expected, and the follow-up to ensure proper transmission of information is not always possible. There was no guarantee that the representatives were the right persons who would work primarily for the interests of the group and not their own [22]. Often because of some socio-cultural rules, certain important categories of stakeholders, such as women and migrants, cannot contribute objectively to the discussions. The transdisciplinary approach requires time and patience to make a relevant diagnostic and to co-develop solutions. Hence, stakeholders, such as farmers, microfinancers, and policymakers who are looking for immediate solutions may not be interested to remain in the IP. Our transdisciplinary approach included feedback loops (Figure 2) in which technologies were tested, evaluated, and tested again. While this approach allows permanent and strong involvement of the actors in the process, this make the results of the research difficult to publish because of frequent changes in the protocol of the field experiments. In addition, although the IPs involved various stakeholders, they were mainly focused on researchers and farmers, as the main obstacle to be addressed was the low productivity of yams in farmers' fields. However, this did not prevent other stakeholder groups from contributing to and benefiting from the discussions. 
It was a challenge to implement such an approach on a traditional crop like yam that is also associated with a variety of superstitious beliefs. Indeed, some of the stakeholders were skeptical at the beginning and told the researchers: "I was born with yam and have been producing it for decades! I do not think you can teach me more than what I know" (D.X., Léo, 2015). "I am a farmer and went to school, but you cannot convince me that if a woman enters a yam field during her menstrual period, that it will not affect its productivity" (N.S., Léo, 2016). We were unknowingly evaluated by some farmers in Léo who provided very degraded soils for the mother trial saying that "if you researchers are able to grow yam on this soil we will definitely believe your message" (N.F., Léo, 2016). In Tiéningboué, we faced a challenge to avoid a distortion of the main purpose of the IP by local politicians. Indeed, during a meeting which was filmed by the media, a political appointee started his statement by thanking the President of Côte d'Ivoire for his efforts to boost yam production. There were expectations by people located in the vicinity of the regions covered by the research to also benefit from our actions. For example, some peoples also expected that we would organize the markets so that they can get good prices.

Farmers were more interested by the mineral fertilization and seed quality than by soil quality. In fact, the impact of fertilizer was rapid, and healthy seed increased the tuber yield. In Léo for instance, an old farmer argued that "soils were fertile in the past but are now degraded because of inappropriate cropping practices because the younger generation of farmers are interested only on immediate yield increase" (NX, Léo, 2019). The application of mineral fertilizer on yam can lead to increased soil organic matter mineralization [23] and therefore, without appropriate accompanying measures, could lead to accelerated soil degradation. The interaction with actors at Midebdo was more difficult than in the other regions. Indeed, despite the good interactions with stakeholders in the IP, it was difficult to have the farmers involved in the field visits and the implementation of the baby trials. We believe that this is cultural and specific to this region. It was observed that some producers who visited the mother trials applied the technologies in their fields in secret. In our opinion this was due to the belief that it is a sign of weakness when you openly show that they are learning from others. This is understandable because the Lobis, the majority ethnic group in this region, are historically known as warriors who do not obey a leader and do not accept submission [24].

The stakeholders recognized some positive aspects of the technologies but also some difficulties that can be overcome (Table 7).

Table 7. Advantages, disadvantages, and propositions to cope with disadvantages (solutions) of the co-developed technologies for yam stakeholders; the information was gained through discussion within innovation platforms and discussion with yam farmers in four yam growing regions in Burkina Faso and Côte d'Ivoire.

\begin{tabular}{|c|c|c|c|}
\hline $\begin{array}{l}\text { Co-Developed } \\
\text { Technologies }\end{array}$ & Advantages & Disadvantages & Solutions \\
\hline Seed cleaning & $\begin{array}{l}\text { Allows good } \\
\text { germination }\end{array}$ & $\begin{array}{l}\text { Time consuming } \\
\text { Risk of poisoning }\end{array}$ & $\begin{array}{l}\text { Equipment for protection } \\
\text { Use of bio pesticides }\end{array}$ \\
\hline $\begin{array}{l}\text { Increased planting } \\
\text { density (1 plant/m²) }\end{array}$ & $\begin{array}{l}\text { Reduces cropped surface } \\
\text { Reduces labor } \\
\text { Allows water harvesting }\end{array}$ & $\begin{array}{l}\text { Additional work to } \\
\text { remake mounds } \\
\text { Destruction of roots } \\
\text { when mounds are } \\
\text { remade due to the small } \\
\text { size of mounds }\end{array}$ & $\begin{array}{c}\text { Remake the mounds } \\
\text { when plants are still } \\
\text { young and have less root } \\
\text { biomass }\end{array}$ \\
\hline $\begin{array}{l}\text { Staking that requires less } \\
\text { wood }\end{array}$ & $\begin{array}{l}\text { Reduces the weeds } \\
\text { pressure } \\
\text { Maintains soil moisture }\end{array}$ & $\begin{array}{l}\text { Lack of wood } \\
\text { Difficult to get } \\
\text { authorization from the } \\
\text { national forestry } \\
\text { commission to get wood } \\
\text { Requires technical } \\
\text { knowledge }\end{array}$ & $\begin{array}{l}\text { Plant trees to have more } \\
\text { wood } \\
\text { Strengthen exchange } \\
\text { with the national forestry } \\
\text { commission }\end{array}$ \\
\hline
\end{tabular}


Table 7. Cont.

\begin{tabular}{|c|c|c|c|}
\hline $\begin{array}{l}\text { Co-Developed } \\
\text { Technologies }\end{array}$ & Advantages & Disadvantages & Solutions \\
\hline $\begin{array}{l}\text { Balanced mineral } \\
\text { fertilization }\end{array}$ & $\begin{array}{l}\text { Improves plant growth } \\
\text { Improves tuber quality }\end{array}$ & $\begin{array}{c}\text { Fertilizer formulation for } \\
\text { yam not available at } \\
\text { market }\end{array}$ & $\begin{array}{l}\text { Train farmers to make } \\
\text { the formulations } \\
\text { Raise awareness among } \\
\text { input sellers about yam } \\
\text { cultivation } \\
\text { Develop the yam and } \\
\text { fertilizer markets }\end{array}$ \\
\hline Organic fertilization & $\begin{array}{l}\text { Improves soil structure } \\
\text { Maintains soil moisture } \\
\text { Improves plants growth } \\
\text { Increases tuber size }\end{array}$ & $\begin{array}{c}\text { Not available } \\
\text { Lack of transportation } \\
\text { Increases weeds } \\
\text { population }\end{array}$ & $\begin{array}{c}\text { Train farmers to make } \\
\text { composts } \\
\text { Intensify livestock } \\
\text { farming }\end{array}$ \\
\hline Organic + Mineral & $\begin{array}{l}\text { Improves plants growth } \\
\text { Improves crop yields }\end{array}$ & $\begin{array}{c}\text { Fertilizer formulation for } \\
\text { yam not available at } \\
\text { market }\end{array}$ & $\begin{array}{l}\text { Train farmers to make } \\
\text { the formulations } \\
\text { Raise awareness among } \\
\text { input sellers about yam } \\
\text { cultivation } \\
\text { Develop the yam market }\end{array}$ \\
\hline
\end{tabular}

It was interesting to note that stakeholders recognized that the increase of the planting density and improved staking allowed for better water harvesting. However, this needs to be further scientifically checked. The lack of wood as a constraint to improving staking is that this technique initially requires larger pieces of wood than the traditional technique. However, these large pieces of wood can be reused up to three times. The lack of organic resources mentioned is a known problem in African agricultural systems and the composting and livestock intensification as proposed by the stakeholders are known solutions. Our mineral fertilization was balanced and provided potassium as well as nitrogen, allowing a better conservation of the tuber and therefore a better quality as recognized by the stakeholders.

\section{Conclusions}

With varying conditions at different regions, our transdisciplinary approach allowed the co-development of technologies, and instigated the interest of farmers to improve yam productivity. The approach required accounting for the knowledge of the stakeholders within the co-development of technologies and evaluation of the results. IPs have proven to be very useful for the co-development of technologies for yam systems. For the IPs to be effective they must be managed appropriately to ensure that the concerns of all parties are properly addressed. It is also important to ensure that all stakeholders in each group are informed of the decisions taken and that their opinions are taken into account by their representatives.

Further research is needed to test and validate the approach and the co-developed technologies in other yam growing regions. There is a need to disseminate the approach in integrating IPs and to upscale the technologies in engaging national institutions of agricultural research and agricultural training and extension. Indeed, up to now the agricultural extension services of Burkina Faso, for instance, had no information on yam production. Also, there is the necessity to develop adequate advocacy for yam at the national level in both countries in order to reach decision-makers, get them to understand the importance of yam, and to develop pro yam policies.

Supplementary Materials: The following are available online at http://www.mdpi.com/2071-1050/12/10/4016/s1, Table S1: Selected biophysical characteristics of the four studied yam growing regions in Burkina Faso and Côte d'Ivoire, Table S2: Selected socio-economic aspects of the four studied yam growing regions in Burkina Faso and Côte d'Ivoire, Figure S1: Fresh tuber yields of yam (D. alata) in the four mother trials at the end of the 2016 (local varieties) and 2018 (improved variety, C18) seasons, Figure S2: Fresh tuber yields of yam (D. rotundata) in 
three mother trials in Burkina Faso (Léo and Midebdo) at the end of the 2017 (local variety) and 2019 (improved variety, R3) seasons and in Côte d'Ivoire (Tiéningboué) at the end of 2016 (local variety) and 2018 (improved variety, R3) seasons.

Author Contributions: D.I.K. prepared the manuscript with inputs from V.K.H. and E.F. All the authors commented on and improved the manuscript. All authors have read and agreed to the published version of the manuscript.

Funding: This work has been done during the YAMSYS project (www.yamsys.org) funded by the food security module of the Swiss Programme for Research on Global Issues for Development (www.r4d.ch) (SNF project number: 400540_152017/1).

Conflicts of Interest: The authors declare no conflict of interest.

\section{References}

1. Price, E.J.; Bhattacharjee, R.; Lopez-Montes, A.; Fraser, P.D. Metabolite profiling of yam (Dioscorea spp.) accessions for use in crop improvement programmes. Metabolomics 2017, 13, 144. [CrossRef] [PubMed]

2. Sangakkara, U.R.; Frossard, E. Home gardens and Dioscorea species-A case study from the climatic zones of Sri Lanka. J. Agric. Rural Dev. Trop. 2017, 115, 55-65.

3. Obidiegwu, J.E.; Akpabio, E.M. The geography of yam cultivation in southern Nigeria: Exploring its social meaning and cultural functions. J. Ethn. Foods. 2017, 4, 28-35. [CrossRef]

4. FAOSTAT. 2016. Available online: http://www.fao.org/faostat/en/\#home (accessed on 5 December 2017).

5. Asiedu, R.; Sartie, A. Crops that feed the world 1. yams. Yams for income and food security. Food Secur. 2010, 2, 305-315. [CrossRef]

6. Frossard, E.; Aighewi, B.A.; Aké, S.; Barjolle, D.; Baumann, P.; Bernet, T.; Dao, D.; Diby, L.N.; Floquet, A.; Hgaza, V.K.; et al. The challenge of improving soil fertility in yam cropping systems of west Africa. Front. Plant Sci. 2017, 8, 1953. [CrossRef] [PubMed]

7. Cornet, D.; Sierra, J.; Tournebize, R.; Ney, B. Yams (Dioscorea spp.) plant size hierarchy and yield variability: Emergence time is critical. Eur. J. Agron. 2014, 55, 100-107. [CrossRef]

8. Pohl, C. From science to policy through transdisciplinary research. Environ. Sci. Policy 2008, 11, 46-53. [CrossRef]

9. Hirsch-Hadorn, G.; Hoffmann-Riem, H.; Biber-Klemm, S.; Grossenbacher-Mansuy, W.; Joye, D.; Pohl, C.; Wiesmann, U.; Zemp, E. Handbook of Transdisciplinary Research; Springer: Dordrecht, The Netherlands, 2008; p. 448.

10. Davies, J.; Maru, Y.; Hall, A.; Abdourhamane, I.K.; Adegbidi, A.; Carberry, P.; Dorai, K.; Ennin, S.A.; Etwire, P.M.; McMillan, L.; et al. Understanding innovation platform effectiveness through experiences from west and central Africa. Agric. Syst. 2017, 165, 321-334. [CrossRef]

11. Vågen, T.-G.; Winowiecki, L.A. Mapping of soil organic carbon stocks for spatially explicit assessments of climate change mitigation potential. Environ. Res. Lett. 2013, 8. [CrossRef]

12. Diby, L.N.; Kouassi, G.; N’Guessan, M.P.; Yao, E.; Oro, F.; Aynekulu, E.; Kassin, E.; Kouame, C.; Coe, R.; Shepherd, K. Cocoa Land Health Surveillance: An Evidence-Based Approach To Sustainable Management of Cocoa Landscapes in the Nawa region, South-West Côte d'Ivoire; Working Paper 193; World Agroforestry Centre: Abidjan, Ivory Coast, 2014. [CrossRef]

13. Baumann, P. Large Scale Prediction of Soil Properties in The West African Yam Belt Based on Mid-Infrared Soil Spectroscopy. Master's Thesis, Swiss Federal Institute of Technology, Zurich, Switzerland, 2016.

14. Chambers, R. Participatory rural appraisal (PRA): Analysis of experience. World Dev. 1994, 22, $1253-1268$. [CrossRef]

15. Pouya, N. Diversité des Pratiques Culturales et Leurs Effets sur les Rendements de L'igname (Dioscorea spp.) Au Burkina Faso: Cas de Léo Dans la Région du Centre-Ouest et de Midebdo Dans la Région du Sud-Ouest. Mémoire de Fin de Cycle en Agronomie; Université Nazi Boni: Bobo-Dioulasso, Burkina Faso, 2015.

16. Ouédraogo, E. Effets de la Diversité des Pratiques Culturales des Producteurs sur le Rendement de L'igname (Dioscorea spp.) en Côte d'Ivoire: Cas de Tiéningboué au Centre-Nord et de Liliyo au Sud-Ouest, Mémoire de DEA; Université Nazi Boni: Bobo-Dioulasso, Burkina Faso, 2017.

17. Budelman, A.; Zander, P.M. Land-use by immigrant baoule farmers in the Tai region, south-west Côte d'Ivoire. Agroforest Syst. 1990, 11, 101-123. [CrossRef] 
18. Taonda, J.-B.; Bertrand, R.; Dickey, J.; Morel, J.L.; Sanon, K. Dégradation des sols en agriculture minière au Burkina Faso. Cah. Agric. 1995, 4, 363-369.

19. Doumbia, S.; Koko, L.; Aman, S.A. L'introduction et la diffusion de la variété d'igname C18 en région centre de Côte d'Ivoire. J. Appl. Biosci. 2014, 80, 7121-7130. [CrossRef]

20. Babo, A. Opportunités sociales et économiques et développement du vivrier marchand à Bouaké (Côte d'Ivoire). Cah. Agric. 2006, 15, 279-283.

21. Gyau, A.; Smoot, K.; Diby, L.N.; Kouame, C. Drivers of tree presence and densities: The case of cocoa agroforestry systems in the Soubre region of Republic of Côte d'Ivoire. Agroforest Syst. 2015, 89, 149-161. [CrossRef]

22. De Sardan, O.J.-P.; Bierschenk, T. Les courtiers locaux du développement. Bull. l'APAD 1993, 12, 2-6.

23. Hgaza, V.K.; Diby, L.N.; Oberson, A.; Tschannen, A.; Tié, B.T.; Sangakkara, U.R.; Aké, S.; Frossard, E. Nitrogen use by yam as affected by mineral fertilizer application. Agron. J. 2012, 104, 1558-1568. [CrossRef]

24. Dory, D. Entre la découverte et la domination: Le Lobi (1800-1960). Eléments d'histoire de la géographie colonial. The Lobi: Between the discovery and the domination. 1800-1960 an exemple of history of colonial geography. Bull. Assoc. Géogr. Franç. Paris 1984, 61, 373-382. [CrossRef]

(C) 2020 by the authors. Licensee MDPI, Basel, Switzerland. This article is an open access article distributed under the terms and conditions of the Creative Commons Attribution (CC BY) license (http://creativecommons.org/licenses/by/4.0/). 